Zofia Rzeźnicka, Maciej Kokoszko, Krzysztof Jagusiak (Łódź)

\title{
Cured Meats in Ancient and Byzantine Sources: HAM, BACON AND TUCCETUM ${ }^{1}$
}

In Antiquity and early Middle Ages fresh meat was a rarity, which was available only to the wealthiest men $^{2}$. Slaughtering animals producing large amounts of meat entailed the problem with its preservation. It was especially important in warm Mediterranean climate - and salting turned out to be the best solution ${ }^{3}$. This process was mentioned both in ancient and Byzantine agronomic and medical sources, and salt-cured meat was known and valued in the whole ancient and Medieval world.

One of the food websites encourages to buy traditional Spanish ham, quoting the legend that hams were created when a pig drowned in a cove with very salty water. Shepherds found the animal and roasted it, discovering that the meat - especially the hind leg - had a pleasant flavor. Later, they realized that salting meat preserved the taste for a long time. They had been improving this process for years until they learned to make the best hams in the world. The fable above explains why Spain has been known for ages for making such excellent hams. One of the first enthusiastic opinions about this delicacy can be found in Strabo's notes. He wrote that delicious cured meats came from Cantabria and western Pyrenees inhabited by Carretanians ${ }^{4}$. Gourmets also treasured hams that came from Lusitania

\footnotetext{
${ }^{1}$ Article developed under the grant UMO 2011/01/B H33/01020.

${ }^{2}$ M. Кокоszкo, Ł. ErLich, Rola mięsa w diecie późnego antyku i wczesnego Bizancjum na podstawie wybranych źródeł literackich. Część I. Zwierzęta hodowlane $w$ sztuce kulinarnej oraz $w$ teorii dietetycznej, PZH 12, 2001, p. 18-20; J.M. Wilkins, S. Hill, Food in the ancient world, Malden, Mass.-Oxford 2006, p. 142.

${ }^{3}$ For salted meat cf. L. GARLAND, The rhetoric of gluttony and hunger in twelfth-century Byzantium, [in:] Feast, fast or famine. Food and drink in Byzantium, ed. W. Mayer, S. Trzcionka, Brisbane 2005, p. 50; J. KODER, Stew and salted meat - opulent normality in the diet of every day?, [in:] Eat, drink and be merry (Luke 12:19). Food and wine in Byzantium. In honour of Professor A.A. M. Bryer, ed. L. Brubaker, K. Linardou, Aldershot, Hampshire 2007, p. 59-72, especially 60-62; I. ANAGNostakis, Byzantine delicacies, [in:] Flavours and delights. Tastes and pleasures of ancient and Byzantine cuisine, ed. I. AnAgnostakis, Athens 2013, p. 81.

${ }^{4}$ Strabonis geographica, III, 4, 11, ed. A. Meineke, vol. I-III, Graz 1969 (cetera: Strabo, Geographica). Cerrentian hams were very priced both in first and fourth century A.D., see MARTIAL, Epigrams, XIII, 54 trans. W.C.A. Ker, vol. I-II, London-New York 1919-1920 (cetera: Martial, Epigrammata); Edictum Diocletiani et Collegarum de pretiis rerum venalium, IV, 1, 8, ed. M. GiACCHERO, vol. I-II, Genova 1974 (cetera: Edictum Diocletiani).
} 
in Hispania Ulterior ${ }^{5}$ and the town of Pomelon, near Aquitaine ${ }^{6}$. But it does not mean that Spain monopolized ancient market of cold meat. This treat was wellknown both all over ancient and early Medieval Europe and in Asia Minor. Varro claimed the best and largest hams were imported to Rome from Gaul ${ }^{7}$ (Comacine and Cavarine) and according to Strabo, the territories between the Rhine and the Saône ${ }^{8}$, were considered to be the places where the best cured meats were produced. Other places mentioned in sources were the North Sea area (around the Scheldt, the Maas and the Rhine), occupied by the tribe of Menapians ${ }^{9}$, the centre of Italy inhabited by the tribe of Mars ${ }^{10}$ and in Asia Minor - city of Kibyra in Ly$\mathrm{cia}^{11}$.

In antiquity several terms for ham were used, which perfectly illustrates the connections between Greek and Latin language. In ancient Greece ham was called kolén ${ }^{12}$, or the Latin word perna ${ }^{13}$ was used. In addition, a Greek loan-word petaso (Greek petasón) was used in Imperium Romanum. Even though both: perna and petaso mean ham, they refer to different parts of pork. The first one means hind legs, the second - was used to name front legs, i.e. pig's shoulder ${ }^{14}$.

\footnotetext{
${ }^{5}$ M. Terenti Warronis rerum rusticarum, II, 4, 11, ed. W.D. Hooper, H.B. AsH, Londinio 1934 (cetera: VARRO, De re rustica).

${ }^{6}$ Athenaei Naucratitae dipnosophistarum libri XV, XIV, 657f-658a (75, 2-14, KAIBEL), rec. G. KaIBEL, vol. I-III, Lipsiae-Berolini 1887-1890 (cetera: Athenaeus of Naucratis, Deipnosophistae).

${ }^{7}$ Varro, De re rustica, II, 4, 10-11; cf. R. LaUR-Belart, Galische Schinken und Würste, SPri 17, 1953, p. 33-40.

${ }^{8}$ Strabo, Geographica, IV, 3, 2.

${ }^{9}$ Martial, Epigrammata, XIII, 54; Edictum Diocletiani, IV, 1, 8. For location of the territory inhabited by this tribe see E. KoniK, W. Nowosielska, Commentary, [in:] Julius Caesar, Wojna gallicka, [in:] Corpus Caesarianum, trans., comm. E. KoniK, W. NowosielsKa, Wrocław 2006, p. 94, note 28.

${ }^{10}$ Edictum Diocletiani, IV, 1, 9.

${ }^{11}$ Athenaeus of Naucratis, Deipnosophistae XIV, 657e (75, 2-5, Kaibel). Hams produced there were undoubtedly best known in the Byzantine Empire.

${ }^{12}$ Iullii Pollicis onomasticon cum annotationibus interpretum, VI, 52, ed. G. Dindorf, vol. I-V, Lipsiae 1824 (cetera: Pollux, Onomasticon). Cf. F. Frost, Sausage and Meat Preservation in Antiquity, GRBS 40.3, 1999, p. 248; A. DALby, Food in the ancient world from A to Z, London-New York 2003, p. 269 (cetera: A. DALBY, Food).

${ }^{13}$ A Greek-English Lexicon, ed. H.G. Liddel, R. Scott, Oxford, 1996, p. 1394, s.v. $\pi \varepsilon ́ p v \alpha$ (cetera: Liddel-ScotT); F. Frost, op. cit., p. 248; A. DALby, Food, p. 269. Varro derived it from the Latin word pes - foot, see VARro, On the Latin language, V, 110, trans. R.G. KenT, vol. I, London, Cambridge 1938. The author of the commentary claims that this etymology is incorrect, cf. R.G. KenT, Commentary, [in:] Varro, On the Latin language, trans. R.G. Kent, vol. I, p. 106, note c. Pliny the Elder writes that with the word perna, because of the shape of the shell which resembled ham, was called one of the sea animals living in the Black Sea, see PlinY, Natural history, XXXII, 54, 154, trans. H. RACKHAM, W.H.S. Jones, D.E. EichHolz, vol. I-X, Cambridge, Mass. 1938-1963 (cetera: Pliny, Historia naturalis). For ham, in Greek language, also word ptérna was used, see Pollux, Onomasticon, II, 193. ${ }^{14}$ J. Frayn, The Roman meat trade, [in:] Food in antiquity, ed. J. Wilkins, D. Harvey, M. Dobson, Exeter 1999, p. 111-112. The opinion that the word perna means salted meat and petaso fresh was negated by J. André. According to him petasones, which were imported to Rome from Gaul (VArro, De re rustica, II, 4, 10-11) must had to be pickled before journey. Moreover, he remarks that Athenaeus of Naucratis (Athenaeus of Naucratis, Deipnosophistae, XIV, 657e-658a [75, 1-2, KAIBEL]) does not make any distinction between them, see J. ANDrÉ, L' alimentation et la cuisine
} 
Romans carefully worked out methods of slaughtering pigs, which nowadays we can explain scientifically. As a result of those methods, the meat was tasty and easy to cure. Usually animals were killed during late autumn ${ }^{15}$ or winter ${ }^{16}$, when they had more fat tissue. To facilitate bleeding, pigs were not fed for twenty-four hours before being slaughtered ${ }^{17}$. During this time, to make sure the meat was not too moist, swine were prevented from drinking ${ }^{18}$. It was also important not to stress or excite the animals, otherwise their meat could become dark and sticky, and could have an unpleasant texture as well as taste ${ }^{19}$. Today we know that these emotional states reduce the level of glycogen, ipso facto rising the level of $\mathrm{pH}$. Maintaining the high level of glycogen is important, because after animal's death, thanks to enzymes, glycogen transforms into lactic acid, which reduces the $\mathrm{pH}$ level in meat, stopping the process of rotting and killing harmful bacteria ${ }^{20}$.

To preserve meat for long periods, it was cured. In order to protect deeper parts of flesh, hams were trimmed with skin, because salt ${ }^{21}$ used for curing made the meat hard ${ }^{22}$ which hindered the distribution of preservative all over it. One of the first mentions about salting hams is found in De agricultura by Cato the Elder. According to him, raw meat should be put with the skin turned down into a pot covered with salt, then the meat should be salted again. Another layer of meat was placed on top of it and covered with a layer of salt ${ }^{23}$, until the vessel was full. It was important that the layers of meat did not touch each other. In the end salt was spread on top of the hams. After five days the meat was taken out, and put back into the vessel, however in the opposite order. After twelve days hams were taken out once again, to remove the salty sediment. They were hung in a draughty

à Rome, Paris 1961, p. 145, note 115. J. Frayn adduces this theory, see EADEM, op. cit., p. 111-112. More information see T.J. LeARY, Martial book XIII: The xenia. Text with introduction and commentary, London 2001, p. 107-108.

${ }^{15}$ D.L. Thurmond, A handbook of food processing in classical Rome. For her bounty no winter, LeidenBoston 2006, p. 211.

${ }^{16}$ Columella, On agriculture, [in:] Lucius Junius Moderatus Columella on agriculture and trees, XII, 55, 3, trans. E.S. Forster, E.H. HefFner, vol. III, London-Cambridge 1955 (cetera: Columella, De re rustica); Palladius, Opus agriculturae, XIII, 6, [in:] Palladii Rutilii Tauri Aemiliani viri inlustris opus agriculturae, de veterinaria medicina, de insitione, ed. R.H. Rodgers, Leipzig 1975 (cetera: Palladius, Opus agriculturae); D.L. Thurmond, op. cit., p. 211.

${ }^{17}$ D.L. Thurmond, op. cit., p. 211.

${ }^{18}$ Columella, De re rustica, XII, 55, 1. Cf. D.L. Thurmond, op. cit., p. 211.

${ }^{19}$ D.L. Thurmond, op. cit., p. 211.

${ }^{20}$ F. Frost, op. cit., p. 245; D.L. Thurmond, op. cit., p. 211.

${ }^{21}$ Salt, apart from having dehydrate properties was also a bacteriostatic, see D.L. ThURMOnd, op. cit., p. 213.

${ }^{22}$ D.L. Thurmond, op. cit., p. 212.

${ }^{23}$ According to Galen for pickling sea or salty water could be also used when the egg put into the water remained afloat. If not, the solution did not contain enough salt, see Galeni de simplicium medicamentorum temperamentis ac facultatibus libri XI, 691, 15 - 692, 4, vol. XI, [in:] Claudii Galeni opera omnia, ed. D.C.G. KüHN, vol. XI-XII, Lipsiae 1826-1827 (cetera: GALEN, De simplicium medicamentorum). The same method is given by Cato, see M. Porci Catonis de agri cultura, LXXXVIII, 1-2, rec. H. KeIL, Lipsiae 1895 (cetera: CAto, De agricultura). 
place for two days. On the third day, the meat was cleaned, greased with oil and smoked. Next, it was greased once more, this time with a mixture of olive oil and vinegar $^{24}$. A similar procedure was described by Columella. In De re rustica he also mentioned that hams should be tightly packed in a vessel sprinkled with dry salt. Additionally the author suggested pressing the pot down with weights, until the brim was almost reached. In his opinion, meat prepared this way could be taken out when needed, and the meat left in the pot was prevented from decay by brine ${ }^{25}$. Another method of preserving was pressing down the meat, which was boned and salted, with the weights. Next, the cured meat was properly rubbed with salt until it was completely ready ${ }^{26}$. When the weather conditions were favorable, the layer of salt was kept on the cut of pork only for nine days, during which the meat was still rubbed. But when it was cloudy and rainy, hams were scrubbed from salt, and put into a pot filled with fresh water in order to remove the rest of residue, but no sooner than after eleven or twelve days. In the end, dried meat was hung up in the larder, where a moderate amount of smoke could reach it. This way of curing was popular especially in midwinter, until the first half of February ${ }^{27}$. The above mentioned methods of preparing animals for butchering and for curing hams were also known in the Byzantine Empire. Information about boning meat before salting can be also found in Geoponica, an agricultural encyclopedia from the $10^{\text {th }}$ century. However, the author of the passage describing this process gave us two new, important pieces of information. In his opinion it was better to use roasted salt for curing and meat should be put in a pot that was previously filled with oil or vinegar $^{28}$. There were many ways to restore the original flavour to the salted meat. It could be cooked twice, first in milk, next in water ${ }^{29}$. Pliny the Elder wrote about reducing the salty flavour with the help of finely ground flour called pollen and linden bark $(\text { philyra })^{30}$. Unfortunately, he did not explain how it should be done. It is possible that the excess of salt was absorbed by the flour that was sprinkled over the meat, and, additionally, by the linden bark that the meat was covered with. We also know about soaking salted fish in water ${ }^{31}$ and this method was certainly also used when other kinds of meat were prepared.

\footnotetext{
${ }^{24}$ CATO, De agricultura, CLXII, 1-3.

${ }^{25}$ Columella, De re rustica, XII, 55, 4.

${ }^{26}$ Columella did not write exactly when.

${ }^{27}$ Columella, De re rustica, XII, 55, 1-3. An American researcher, Frank J. Frost, noticed that this method is identical to this used today in northern Italy to make prosciutto crudo and elsewhere to make country hams, see F. Frost, op. cit., p. 245.

${ }^{28}$ Geoponica sive Cassiani Bassi Scholastici de re rustica eclogae, XIX, 9, 1-4, rec. H. BeCKH, Lipsiae 1895.

${ }^{29}$ Apicius. A critical edition with an introduction and an English translation of the Latin recipe text Apicius, I, 10, ed. Сh. Grocock, S. Grainger, Blackawton-Totnes 2006 (cereta: De re coquinaria).

${ }^{30}$ PLINY, Historia naturalis, XXIV, 1, 3.

${ }^{31}$ Terence, The Brothers, 380, [in:] Terence, trans. J. SARgeaunt, vol. II, London-New York 1920.
} 
Salted meat in Greek was called tárikhos ${ }^{32}$. This term was also used for other products preserved in brine like fish ${ }^{33}$ or vegetables ${ }^{34}$. Galen and Oribasius wrote that meat that came from fattened mature pigs was best for salting. The physicians mentioned above, as well as Aetius of Amida ${ }^{35}$, claimed that one of the most important features of meat was moisture, because when an animal was old, its flesh became tough ${ }^{36}$ and indigestible ${ }^{37}$. On the other hand, large amounts of moisture in tender meat of young pigs were reduced, owing to the drying properties of salt, so the product decreased its volume ${ }^{38}$. According to medical sources well-selected salted meat, was of the same as the fresh one and in many respects it was even more valuable. For example it was believed that this sort of tárikhos, regardless of the species of the animal, diluted thick and sticky humors ${ }^{39}$. Although Greek and Byzantine physicians warned that salted meat caused production of black bile $e^{40}$ and could trigger fevers, especially after big physical effort, such as long journeys ${ }^{41}$, it was considered to be a healthy element of a $\operatorname{diet}^{42}$. Moreover, pork was valued for its dietetic properties. It was regarded to be light and the most nutritious of all

${ }_{32}$ A. Dalby, Food, p. 95. Cf. A. Karpozelos, Realia in Byzantine epistolography XIII-XV c., BZ 88, 1995, p. 76.

${ }_{33}$ A. Dalby, Food, p. 95, 169, 313, 334, 336-337; M. Koкоszko, Ryby i ich znaczenie w życiu codziennym ludzi późnego antyku i wczesnego Bizancjum, Łódź, 2005, p. 41, 107-109, 317-329. Cf. IDEM, Kuchnia i dietetyka późnego antyku oraz Bizancjum. Kilka uwag na temat spożycia, sporzadzania, przyrządzania, wartości dietetycznych i zastosowań medycznych konserw rybnych $w$ antycznej i bizantyńskiej literaturze greckiej, AUL.FH 80, 2005, p. 7-25.

${ }^{34}$ Galeni de temperamentis libri III, 661, 16, [in:] Claudii Galeni opera omnia, ed. D.C.G. KüHN, vol. I, Lipsiae 1821.

${ }^{35}$ Aetius of Amida in his treatise writes generally about pickling the meat of different species of animals: mammals, birds and fish.

${ }^{36}$ Galeni de alimentorum facultatibus libri III, 746, 6-11, [in:] Claudii Galeni opera omnia, ed. D.C.G. KüHN, vol. VI, Lipsiae 1823 (cetera: GALEN, De alimentorum facultatibus); Oribasii collectionum medicarum reliquiae, IV, 1, 36, 3 - 37, 1, ed. I. RAEDER, vol. I-IV, Lipsiae-Berolini 1928-1933 (cetera: OrIbasius, Collectiones medicae); Aetii Amideni libri medicinales I-VIII, II, 149, 1-14, ed. A. Olivieri, Lipsiae-Berolini 1935-1950 (cetera: Aetius of Amida, Iatricorum libri).

${ }^{37}$ Oribasius, Collectiones medicae, IV, 1, 39, 1 - 40, 1; Aetius of Amida, Iatricorum libri, II, 149, 11-12. A $6^{\text {th }}$ century physician, Anthimus, writes in the same way about salted beef and ox (carnes uaccinae uel bubulinae insalatae), see Anthimus, On the observance of foods. De observatione ciborum, 12, ed., trans. M. Grant, Totnes-Blackawton 2007 (cetera: Anthimus, De observatione ciborum).

${ }^{38}$ Galen, De alimentorum facultatibus, 746, 9-11, vol. VI; Oribasius, Collectiones medicae, IV, 1, 36, 5 - 37, 1; Aetius of Amida, Iatricorum libri, II, 149, 8-10.

${ }^{39}$ Galen provided this kind of information writing about salted fish, see GALEN, De alimentatorum facultatibus, 747, 4-11. Oribasius, as well as Aetius of Amida, quoted this opinion when writing generally about curing meat, see Oribasius, Collectiones medicae, IV, 1, 39, 1 - 40, 1; Aetius of AMIDA, Iatricorum libri, II, 149, 12-13.

${ }^{40}$ Oribasius, Collectiones medicae, III, 9, 1, 1-2, 5 (tárikhos: III, 9, 1, 3); Aetius of Amida, Iatricorum libri, II, 246, 1-9 (tárikhos: II, 246, 3). Both physicians write about the meat of quatropedes.

${ }^{41}$ Galeni in Hippocratis de victu acutorum commentaria IV, 739, 8-13, [in:] Claudii Galeni opera omnia, ed. D.C.G. KüHN, vol. XV, Lipsiae 1828.

${ }^{42}$ Oribasius, Collectiones medicae, III, 2, 19, $1-20,1$. 
kinds of meat. It was also said to be the tastiest, not only due to a balanced amount of juices, but also because it contributed to keeping humoral balance inside the human body ${ }^{43}$. Maybe that is why Galen claimed that eating pork in the restorative diet $^{44}$ should start with fresh pig trotters boiled with barley soup called ptisáne ${ }^{45}$ then, ham ${ }^{46}$ and other food should be introduced gradually. It was said that cured pork was also good, eaten with lentil soup called phakét ${ }^{47}$ and phakoptisáne $e^{48}$ a liquid meal made of lentils and groats ${ }^{49}$. This kind of food was believed to be tasty and light. Considering all these advantages of cured pork, there is no wonder that ham was also applied as remedy. It was one of the ingredients of the cure for arthritis recommended by the physician of Pergamon. In De simplicium medicamentorum temperamentis ac facultatibus he wrote about treating this condition with old cheese that was first soaked in a stock (zomós) made with cured pig's leg. The cheese was ground in a mortar and put on the painful part of the body. Thanks to this mixture the patient's skin opened without any cutting and every day new pieces of callus were flowing out. When all the cheese was used up, the patient got some fresh one and when it became old, he applied the medicine on his own. He also taught others, who had the same problem, to make this ointment ${ }^{50}$. This kind of treatment must have been effective in the following centuries because it was well known to Oribasius ${ }^{51}$, Aetius of Amida ${ }^{52}$, Alexander of Tralles ${ }^{53}$ and Paul of Aegina $^{54}$. They all almost literally quoted the story given by Galen, with one little,

\footnotetext{
${ }^{43}$ M. Кокоszко, Smaki Konstantynopola, [in:] Konstantynopol - Nowy Rzym. Miasto i ludzie w okresie wczesnobizantyńskim, ed. M.J. LeszKA, T. WolińsKa, Warszawa 2011, p. 494.

${ }^{44}$ Galeni de methodo medendi libri XIV, 488, 11-16, [in:] Claudii Galeni opera omnia, ed. D.C.G. KüHN, vol. X, Lipsiae 1825 (cetera: Galen, De methodo medendi).

${ }^{45}$ For some recipes for this barley soup called tisana in Latin, see De re coquinaria, V, 5, 1-2. Oribasius recommended cooking pig trotters with ptisáne, see OrIBAsIUs, Collectiones medicae, IV, 1, 25, 1-2. For more information about medical uses of ptisáne, see M. Koкoszko, Z. RzeźNicka, K. JAGUsiak, Health and culinary art in antiquity and early Byzantium in the light of De re coquinaria, SCer 2, 2012,

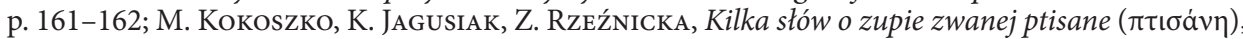
ZW 18, 2013, p. 282-292.

${ }^{46}$ Galen, De methodo medendi, 489, 7, vol. X.

${ }^{47}$ Galen, De alimentatorum facultatibus, 527, 14 - 528, 1, vol. VI; Oribasius, Collectiones medicae, IV, $1,25,1-3$.

${ }^{48}$ Galen, De alimentatorum facultatibus, 528, 1-2, vol. VI; Oribasius, Collectiones medicae, IV, 1, $25,3-26,1$.

${ }^{49}$ In De re coquinaria we can find recipes for lentil dishes (lenticula), see De re coquinaria, V, I2, 1-3, but there are no recipes for phakoptisáne.

${ }^{50}$ Galen, De simplicium medicamentorum, 270, 18 - 271, 13, vol. XII.

${ }^{51}$ Oribasii synopsis ad Eustathium filium, IX, 58, 1, 1 - 3, 1, [in:] Oribasii synopsis ad Eustathium filium et libri ad Eunapium, ed. I. RAEDER, vol. VI, 3, Lipsiae 1964 (cetera: Oribasius, Synopsis ad Eustathium filium).

${ }^{52}$ Aetius of Amida, Iatricorum libri, II, 102, 1-10.

${ }^{53}$ Alexandri Tralliani therapeutica, 561, 5-11, vol. II, [in:] Alexander von Tralles, vol. I-II, ed.

T. Puschmann, Amsterdam 1963 (cetera: Alexander of Tralles, Therpeutica).

${ }^{54}$ Paulus Aegineta, III, 78, 24, 9-13; VII, 3, 19, 98-101, ed. I.L. HeibERg, vol. I-II, Lipsiae-Berolini 1921-1924 (cetera: Paul of Aegina, Epitome).
} 
but important, complement. According to them, cheese should be not only old ${ }^{55}$, but also fat ${ }^{56}$ and savoury ${ }^{57}$, moreover, the stock should be cooked with an old ${ }^{58}$, fat ${ }^{59}$ ham.

Furthermore, Aetius of Amida prescribed more complex ${ }^{60}$ medicine for the same illness ${ }^{61}$, which, in addition to the meat stock from an old ham and a piece of an old goat cheese, should contain i.a. some gum called ammoniakón, hyssop, deer bone marrow, wax and beef suet ${ }^{62}$. Almost identical ingredients were mentioned by Oribasius in Synopsis ad Eustathium filium, but this time in the chapter devoted to tumors ${ }^{63}$, which means that a very similar medicine was used in curing different types of ailments. From this passage we learn that instead of zomós made form the old ham he proposed using its fat, another modification was adding cow or goat cheese. Moreover the author claimed that recipe came from Galen's medical treatises ${ }^{64}$, so the medicament was used in the $2^{\text {nd }}$ century A.D. More details about this therapy were given to us by Paul of Aegina ${ }^{65}$. According to him the sore part of the body should be first rubbed with some firm vinegar, next with the ammoniakón gum for many days. Then, a medicine with an emollient properties, such as an ointment made from pérna should be used ${ }^{66}$. In his opinion, a dressing, called polymágmaton, made from ham ${ }^{67}$ that probably was first chewed, was used in curing illnesses of joints called ankýlosis ${ }^{68}$.

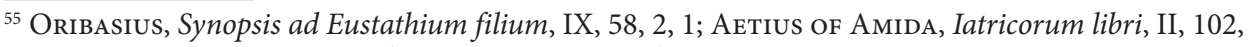
4; Alexander of Tralles, Therpeutica, 561, 7, vol. II; Paul of Aegina, Epitome, III, 78, 24, 10; VII, 3, 19, 98.

${ }^{56}$ Paul of Aegina, Epitome, VII, 3, 19, 98.

${ }^{57}$ Oribasius, Synopsis ad Eustathium filium, IX, 58, 2, 1; AleXander of Tralles, Therapeutica, 561, 7, vol. II; Paul of Aegina, Epitome, III, 78, 24, 10-11; VII, 3, 19, 99.

${ }^{58}$ Aetius of Amida, Iatricorum libri, II, 102, 3-4; Paul of Aegina, Epitome, III, 78, 24, 11.

${ }^{59}$ Paul of Aegina, Epitome, III, 78, 24, 11; VII, 3, 19, 100-101.

${ }^{60}$ It is possible that it is the same medicine mentioned by Paul of Aegina. He writes about more complex medicine for arthritis (PAul of Aegina, Epitome, III, 78, 24, 1-25, 2) prepared from ham with an addition of some myrrh oil or without it, see PaUl of Aegina, Epitome, III, 78, 24, 13-15.

${ }^{61}$ Aetius of Amida, Iatricorum libri, XII, 65, 1-42.

${ }^{62}$ Aetius of Amida, Iatricorum libri, XII, 65, 22-26.

${ }^{63}$ Oribasius, Synopsis ad Eustathium filium, VII, 34, 1, 1 - 5, 1. Cf. Paul of Aegina, Epitome, IV, $55,1,18-19$.

${ }^{64}$ Oribasius, Synopsis ad Eustathium filium, VII, 34, 4, 3 - 5, 1.

${ }^{65}$ Paul of Aegina, Epitome, IV, 32, 1, 1 - 2, 16.

${ }^{66}$ Paul of Aegina, Epitome, IV, 32, 2, 11-16.

${ }^{67}$ Paul of Aegina, Epitome, IV, 55, 1, 18.

${ }^{68}$ Paul of Aegina, Epitome, IV, 55, 1, 1-21.
} 
In the ancient world, ham was an expensive $e^{69}$ delicacy $^{70}$, served on special occasions $^{71}$. Recently salted ${ }^{72}$ and streaky ${ }^{73}$ meat was valued most. According to the sources, it was eaten $\mathrm{raw}^{74}$, smoked $^{75}, \mathrm{dry}^{76}$ or cooked ${ }^{77}$. Accurate instructions how to make this dish were given in De re coquinaria - the one and only remaining cookbook, which was supposed to be written by a Roman gourmet Apicius. Reading the recipes, we can assume that sweet hams were very popular. To make the meat sweet, it was cooked in water with a large number of figs ${ }^{78}$. The use of those fruits was recommended in all the recipes for hams in De re coquinaria, and the phrase $u t$ solet $^{79}$ (as usually) given in one of the recipes, shows that it was a common practice. Perna could be put into this kind of stock, flavoured with bay leaves. When it was almost soft, the skin was removed, the meat was cut partway and honey was poured inside. Next, it was wrapped in a pastry made from flour and olive oil, and baked in an oven. The dish was served hot ${ }^{80}$. Cooked ham could also be served with diced sweet bread and boiled grape must (caroenum), spiced wine or sweet bread made with grape must - mustace $^{81}$. Another recipe used petaso, that was probably a pig's shoulder. This recipe is unique, because usually the instructions did not mention quantities of ingredients, and this time the author mentioned that 25 figs and 2 librae $e^{82}$ of barley were needed. All this should

${ }_{69}$ Edictum Diocletiani, IV, 1, 8-9. In Rome it was often given as a proof of gratitude, see Persius, Satura, III, 75, [in:] Persi Flacci et D. Ivni Ivvenalis Saturae, ed. W.V. Clausen, Oxford 1992 (cetera: Persius, Satura).

${ }^{70}$ In comedies by Plautus characters are always hungry for this delicacy, see Plautus, Captivi, 850; 903; 908, [in:] T. Macci Plauti comodiae, rec. W.M. Lindsay, vol. I, Oxonii 1946 (cetera: Plautus, Captivi); Plautus, Curculio, 323, [in:] T. Macci Plauti comodiae..., 1946 (cetera: Plautus, Curculio). Ham is also mentioned in comedies quoted by Athenaeus, see AthenaEus of NaUCratis, Deipnosophistae, III, 95a (48, 6, KAIBEL); IX, 366a-b (1, 10-13, KAIBEL).

${ }^{71}$ Plautus, Pseudolus, 166, ed. E.H. Sturtevant, F.E. Brown, F.W. Schaefer, J.P. Showerman, New Haven-London 1932 (cetera: Plautus, Pseudolus); Petronii Arbitri Satyricon reliquiae, 66, ed. K. MüLleR, Monachii-Lipsiae 2003.

${ }^{72}$ Martial, Epigrammata, XIII, 55.

${ }^{73}$ Martial, Epigrammata, III, 77, 6.

${ }^{74}$ Ovidius, Fasti, VI, 158, [in:] Ovid's Fasti, trans. J.G. Frazer, London-Cambridge, Mass. 1959 (cetera: Ovidius, Fasti).

${ }^{75}$ Horace, Satire, II, II, 117, [in:] Horace, Satires, Epistles and Ars Poetica, trans. H. Rushton Fairclough, London-Cambridge 1961 (cetera: Horace, Satura).

${ }^{76}$ Juvenal, Satura, VII, 119, [in:] Persi Flacci et D. Ivni Ivvenalis Saturae, ed. W.V. Clausen, Oxford 1992 (cetera: JuvenaL, Satura).

${ }_{77}$ Plautus, Pseudolus, 166; De re coquinaria, VII, 9, 1-3.

${ }^{78}$ De re coquinaria, VII, 9, 1-3.

${ }^{79}$ De re coquinaria, VII, 9, 2.

${ }^{80}$ De re coquinaria, VII, 9, 1 . Modern version of this recipe was published in cookbooks by S. Grainger and P. FaAs, see S. Grainger, Cooking Apicius. Roman recipes for today, Blackawon-Totnes 2006, p. 62-63; P. FAAs, Around the Roman table. Food and feasting in ancient Rome, trans. S. Whiteside, Chicago 2005, p. 268.

${ }^{81}$ De re coquinaria, VII, 9, 2. The recipe for mustacei is given by Cato, see CATo, De agricultura, CXXI.

${ }^{82} \mathrm{Libra}=327,4$ gram. 
be cooked with meat, next the flesh was boned, the fat was discarded, and before putting the ham into an oven, it was covered with honey. Partly baked petaso was served with a sauce prepared with wine, raisin wine, some rue and pepper. It was also used for soaking mustacei, which, in the end, were served with roasted ham ${ }^{83}$.

Another favoured piece of pork was lardum or laridum, which, like ham, was prepared in winter ${ }^{84}$. According to Andrew Dalby this product was an equivalent of today bacon ${ }^{85}$, that is the lower part of pork side, or a cut of salted pork, which after frying was added to different types of dishes to add flavour. In Rome, especially in the Republican period ${ }^{86}$ and later, lardum was a precious ${ }^{87}$ stock of a $\operatorname{larder}^{88}$. This delicacy was served on special occasions ${ }^{89}$, e.g. birthday ${ }^{90}$. Salted bacon could have been eaten raw $^{91}$ or hot ${ }^{92}$. Prepared in a special way, it became famous - a dish made from lardum and overboiled broad bean-mash called puls ${ }^{93}$, was dedicated to the Roman goddess Carna ${ }^{94}$. Moreover, because salted bacon was easy to store, it became one of the basic elements of the Roman army provisions ${ }^{95}$.

A word halistón $n^{96}$ was used in Greek for bacon, what suggest that it was salted $^{97}$. Later, Byzantine Greek language adapted two terms similar to Latin lardum:

${ }_{83}$ De re coquinaria, VII, 9, 3. For modern version of this recipe both, for meat and mustacei see A. Dalby, S. Grainger, The classical cookbook, London 2000, p. 109-111.

${ }^{84}$ Palladius, Opus agriculturae, XIII, 6.

${ }^{85}$ A. Dalby, Food, p. 269.

${ }^{86}$ Among Plato's characters laridum is said to be one of the favourite dishes, see Plautus, Menaechmi, 210, [in:] T. Macci Plauti comodiae, rec. W.M. Lindsay, vol. I, Oxonii 1946; Plautus, Captivi, 847; 903.

${ }^{87}$ Edictum Diocletiani, IV, $1,7$.

${ }^{88}$ Isidori Hispalensis episcopi etymologiarum sive originum libri XX, XX, II, 24, rec. W.M. LINDSAY, vol. II, Oxonii 1957.

${ }^{89}$ Ovid, Metamorphoses, VIII, 648, trans. F.J. Miller, vol. I, Cambridge-London 1951 (cetera: Ovidius, Metamorphoses).

${ }^{90}$ JuvenAL, Satura, XI, 83-84.

${ }^{91}$ A. Dalby, Tastes of Byzantium. The cuisine of a legendary Empire, London-New York, 2010, p. 210.

${ }^{92}$ Plautus, Captivi, 847. Ovidius writes about cooking smoked bacon in the water, see Ovidius, Metamorphoses, VIII, 647-650.

${ }^{93}$ Pliny writes about an ancient rural tradition sacrificing to the gods puls made from broad bean, see PLINY, Historia naturalis, XVIII, 30, 118.

${ }^{94}$ This kind of dish was prepared on June Calends, see Ovidius, Fasti, VI, 169-170; Macrobius, Saturnalia, I, 12, 33, [in:] Macrobius, Saturnalia, books I-II, ed., trans. R.A. KAster, vol. I, Cambridge-London 2011. It was believed that that day gods listen to the prayers, see Ovidius, Fasti, I, 175-182.

${ }_{95}$ The Scriptores Historiae Augustae, Hadrian, X, 2, trans. D. Magine, vol. I, London-New York 1922; R.W. Davies, The Roman military diet, Brit 2, 1971, p. 124; J. Rотн, The logistics of the Roman army (264 B.C.-235 A.D.), Leiden-Boston 1998, p. 29-30. According to the researcher salted pork was a favorite military item because of low prices and easy preservation.

${ }^{96}$ The identity of medical recommendations of Byzantine and Latin physicians presented in the next part of the article proves that terms lardum and halistón relate to the same product.

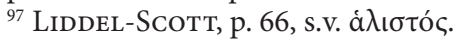


lárdos ${ }^{98}$ and lardé9 $e^{99}$. The number of references in the sources implies that it was commonly eaten in the Western Europe. We know that it was especially consumed by the Franks ${ }^{100}$. A $6^{\text {th }}$ century doctor, Anthimus, who lived among them, recommended eating bacon that was properly cooked ${ }^{101}$ and cooled. In his opinion, this kind of a product was light and prevented constipation, but the doctor warned against the consumption of pork skin, because it was indigestible. He also objected to eating fried bacon, because this kind of heat treatment deprived it of the fat, and that made the meat dry. In this form it was harmful to the organism and contributed to the production of bad juices and caused indigestion ${ }^{102}$. It seems that the author of the recipe from De re coquinaria knew the above mentioned requirements, because he wrote that bacon should be cooked in water flavored with a big amount of dill, a few drops of olive oil and a pinch of salt ${ }^{103}$. From other sources we know that it could also be stuffed into a calf's maw ${ }^{104}$, and the fat that was rendered from the meat was added to broad beans ${ }^{105}$ and other vegetables and dishes for the sake of the flavor. Probably the scraps of the meat that remained after rendering were added to meals in form of pork rinds. From De observatione ciborum we find out that lardum was eaten raw. Anthimus was interested in this practice, that was especially common among the Franks. He observed that people who ate it this way were healthier than others. This sort of meat was not only considered to be healthy, but was also used as medicine for intestinal diseases and to regulate the work of internal organs. It was believed that compresses prepared from a large slice of bacon put on different kinds of wounds, stopped their running and purified them. In the opinion of the physician, lardum helped fighting parasites ${ }^{106}$ present in the digestive system, but he did not describe how the treatment should proceed. We think, that we can be almost sure that it was the same method as the one described in Byzantine medical sources. According to Oribasius ${ }^{107}$, Aetius of

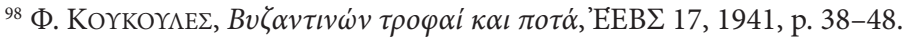

${ }^{99}$ Constantini Porphyrogeniti Imperatoris de cerimoniis aulae Byzantinae libri duo, 1, 84 - 2, 56, 464

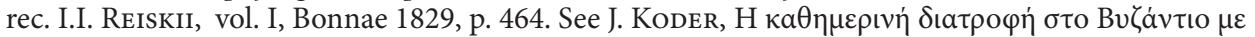

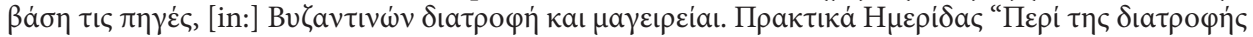

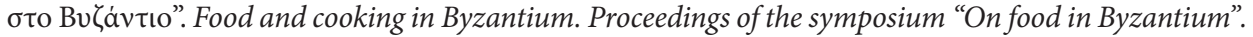
Thessaloniki Museum of Byzantine Culture 4 November 2001, ed. D. Papanikola-Bakritzi, Athens 2005, p. 21.

${ }^{100}$ Anthimus, De observatione ciborum, 14.

${ }^{101}$ Bacon should be cooked longer if it was from a ham, see Anthimus, De observatione ciborum, 14.

102 Anthimus, De observatione ciborum, 14.

${ }^{103}$ De re coquinaria, VII, $9,4$.

${ }^{104}$ Anthimus, De observatione ciborum, 20.

${ }^{105}$ Horace, Satura, II, VI, 63-64; Martial, Epigrammata, V, 78, 10.

${ }^{106}$ Anthimus, De observatione ciborum, 14.

107 Oribasii Collectionum medicarum eclogae medicamentorum, LVII, 7, 1 - 8, 1, [in:] Oribasii collectionum medicarum reliquiae, vol. IV, libros XLIX-L, libros incertos, eclogace medicamentorum, indicem continens, ed. I. RAEDER, Lipsiae-Berolini 1933 (cetera: ORIBASIUs, Eclogaemedicamentorum).
} 
Amida ${ }^{108}$ and Paul of Aegina ${ }^{109}$ halistón $n^{110}$ was an effective medicine for parasites such as askarídes and hélminthes. Halistón formed in the shape of a finger ${ }^{111}$ was used rectally as a suppository ${ }^{112}$. The meat should stay there as long as it was possible $^{113}$ and when it was taken out it was replaced with a new portion ${ }^{114}$. Aetius of Amida added that during this therapy the rectum should also be carefully washed and an ointment should be applied ${ }^{115}$. Other medical uses of bacon can be found in De medicamentis by Marcellus Empiricus, a Gaulish doctor, who lived at the turn of $4^{\text {th }}$ and $5^{\text {th }}$ century. He recommended very old (vetustissimum) lardum, pounded in a mortar, as a medicine for aching and suppurating ears. Next, a piece of wool soaked with the juice from the mortar was placed into the ear. Such dressing should be changed, as in the above cas $\mathrm{e}^{116}$. The same authority wrote that in order to remove objects that got stuck in the patient's body, a ligature made from cooked fat bacon should be prepared ${ }^{117}$. Curing properties of bacon must have also been known in ancient Rome, and some of them are mentioned by Pliny the Elder in Historia naturalis. In order to stop spitting blood, a mixture made from three egg yolks, three ounces of old lardum, honey and three cyathi ${ }^{118}$ of old wine was used. A portion of the mass the size of a hazelnut should be taken orally in water ${ }^{119}$. A dressing prepared from cooked bacon which was wrapped around the limb was used in treating fractures ${ }^{120}$. According to the author, bacon was also an efficient antidote for mercury poisoning ${ }^{121}$.

A large number of references in sources make the way of preparing the products described above clear to us. Production and consumption of ham and bacon are still alive in European tradition, therefore we not only know how they could look in ancient times, but we can even imagine their taste. Unfortunately, as in the case of tuccetum, which is a very enigmatic nourishment ${ }^{122}$, we do not always have

\footnotetext{
${ }^{108}$ Aetius of AmidA, Iatricorum libri, IX, 38, 1-28.

${ }^{109}$ Paul of Aegina, Epitome, IV, 57, 14, 1 - 16, 12.

${ }^{110}$ Oribasius, Eclogae medicamentorum, LVII, 7, 14 - 8, 1; Aetius of Amida, Iatricorum libri, IX, 38, 31-36 (halistón: IX, 38, 31); PAul of AEgina, Epitome, IV, 57, 15, 6 - 16, 1.

${ }^{111}$ Aetius of Amida, Iatricorum libri, IX, 38, 32.

${ }^{112}$ A piece of bacon was kept in the rectum with bandages, see OrIBAsIUs, Eclogae medicamentorum, LVII, 7, 15 - 8, 1; Paul of Aegina, Epitome, IV, 57, 15, 7.

${ }_{113}$ Oribasius, Eclogae medicamentorum, LVII, 7, 15 - 8, 1; Aetius of Amida, Iatricorum libri, IX, 38, 33-34; Paul of Aegina, Epitome, IV, 57, 15, 6 - 16, 1.

${ }^{114}$ Paul of Aegina, Epitome, IV, 57, 16, 1.

${ }^{115}$ Aetius of Amida, Iatricorum libri, IX, 38, 34-35.

${ }^{116}$ Marcelli de medicamentis liber, VIIII, 68, ed. G. Helmreich, Lipsiae 1889 (cetera: Marcellus EMPIRICUs, De medicamentis).

${ }^{117}$ Marcellus EmpIricus, De medicamentis, XXXIIII, 47.

${ }^{118}$ Cyathus $=0,0451$.

${ }^{119}$ PLINY, Historia naturalis, XXIX, 11, 43-44.

${ }^{120}$ PLINY, Historia naturalis, XXVIII, 65, 227.

${ }^{121}$ PLINY, Historia naturalis, XXVIII, 45, 158.

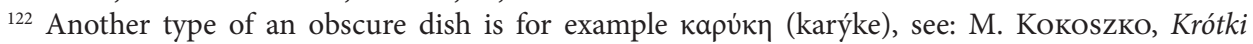

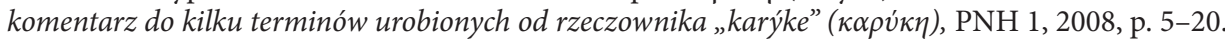


that sort of information. Here, in order to complete our considerations concerning cured meat, we would like to present only a few propositions of interpretation of this term that can be found in sources and modern scholarship. Some Latin authors just mention tuccetum without any closer description, in literature most comments on this word refer to fragments from Satura II by Persius, Metamorphoses by Apuleius and Adversus nationes libri VII by Arnobius. In our opinion it is worth looking at the context in which the word was used by the ancients. Apuleius mentioned it three times. The first passage containing the noun suggests that it was well-smelling delicacy ${ }^{123}$. The second concerns using tuccetum to add the flavour to some kind of purée dish ${ }^{124}$. Finally the third one informs us generally about preparing this food ${ }^{125}$. In Persius' satire we can find only a phrase tuccetaque crassa ${ }^{126}$, which we can translate as "fat tucceta". Also Arnobius limited himself to a casual description of the product, writing glacialia conditione tucceta ${ }^{127}$ what we can understand as tucceta that were cold, covered with ice or brought from the north.

In modern publications there can be found many interpretations of this term, since every researcher gives it a different meaning. An English $19^{\text {th }}$ century expert on antiquity, Henry Nettleship, in Contributions to Latin lexicography derived the mysterious word from tucca, which he translated as "sauce"128, quoting the Greek phrase katákhyma zomoú. On the other hand, Albert J. Carnoy supposed that tucca was a diminutive from tuccetum or tucdum, which he explained as "bacon"129. By contrast, in the Latin-Polish dictionary edited by Marian Plezia, under tuccetum we find the information that it was a kind of cured meat or pâté ${ }^{130}$. A partial confirmation of this thesis seems to be translation of the second satire by Persius, proposed by George G. Ramsay where the word "ragout"131 was used. Nevertheless, Catherine C. Keane translated tuccetum as "sausage" 132 in the dictionary added to the selection of Roman satires, and the the same interpretation is given by J. Arthur Hanson in his version of Metamorphoses by Apuleius ${ }^{133}$. What is interesting, William Adlington, the author of prewar translation of the same work, translated

\footnotetext{
${ }^{123}$ Apuleius, Metamorphoses, II, 7, ed., trans. J.A. Hanson, vol. I, Cambridge, Mass.-London 1989 (cetera: Apuleius, Metamorphoses).

${ }^{124}$ Apuleius, Metamorphoses, IX, 22.

${ }^{125}$ Apuleius, Metamorphoses, VII, 11.

${ }^{126}$ Persius, Satura, II, 42.

${ }^{127}$ Arnobii adversus nationes libri VII, II, 42, rec. A. ReIfFerscheId, Vindobonae 1875.

${ }^{128}$ H. NetTleship, Contributions to Latin lexicography, Cambridge-New York-Melbourne-MadridCape Town-Singapore-Sāo Paolo-Dheli-Dubai-Tokyo 2010, p. 602.

129 A.J. CaRnoy, The reduplication of consonants in vulgar Latin, MPh 3, 1917/1918, p. 170.

${ }^{130}$ Słownik łacińsko-polski, ed. M. PlezIA, vol. V, Warszawa 2007, p. 453, s.v. tuccetum.

${ }^{131}$ Persius, Satura, II, 42. Both, pâté and ragout, are made from chopped meat.

${ }^{132}$ C.C. KeAne, Vocabulary, [in:] EADEM, A Roman verse satire reader: selection from Lucilius, Horace, Persius, and Juvenal, Mundelein 2010, p. 139.

${ }^{133}$ J.A. Hanson remarks that this translation is uncertain, cf. IDEM, Commentary, [in:] ApUleIUs, Metamorphoses, vol. I, Cambridge, Mass.-London 1989, p. 73, note 1.
} 
tuccetum as "haggis"134, i.e. Scottish dish made from sheep offal stewed with other ingredients in the stomach of the mentioned animal. A completely new point of view on this subject was given by Emilio Sereni. In his opinion the word refers to the cut of beef ${ }^{135}$ or pork ${ }^{136}$ meat preserved with lard. Moreover he indicates connections between Spanish tocino (bacon) $)^{137}$ and Portugal toucinho (lard/bacon) $)^{138}$. This interpretation finds support in conclusions made by Jacques André, who in his deliberations associated tuccetum with Lithuanian taukai (fat $)^{139}$ and claimed that it was an ancient equivalent of a French dish called rillettes ${ }^{140}$ - salted, diced or minced meat stewed for a long time in fat. Some light on the problem is shed by a note made by Latin commentators of Persius writings quoted by Francis Cairins in her Roman lyric. Collected papers on Catullus and Horace. According to annotations refering to Satire II, tuccetum was a delicacy that came from Galia Cisalpina that was prepared by curing beef or pork in greasy brine (condimentis quibusdam crassis oblita ac macerata) and that is why it could be preserved even for a whole year ${ }^{141}$. Furthermore the same author of the commentary gave us new meaning of the word, namely sauce for roast meat, he also derived from tuccetum cognomen of one of Virgil's friend, called Publius Tucca ${ }^{142}$. An interesting analogy to this sobriquet can be found in De magistratibus by John the Lydian ( $6^{\text {th }}$ century), who mentioned name Toúkkas, and he explained it as keobóros (meat-eater) ${ }^{143}$.

From the few pieces of information from the Latin sources and presented above proposals of translation we can assume several general conclusions about the nature of tuccetum. Without a doubt it was a meat dish prepared from beef or pork, that was probably cut into pieces. From the comments to ancient literature we learn that this kind of food, owning to preservatives such as fat, and maybe salt, could have been stored for a long time. Probably that is why Apuleius wrote about its characteristic aroma ${ }^{144}$. According to Metamorphoses we can suppose that the product was an individual meal or it was used as addition to other courses. Finally, it is worth mention that although the tradition of making tuccetum almost for sure

\footnotetext{
${ }^{134}$ Apuleius, The golden ass. Being the metamorphoses of Lucius Apuleius, II, 7, trans. W. AdLington, London-New York 1922.

${ }^{135}$ E. SERENI, Vita e tecniche forestali nella Liguria antica, AIAC 19, 1997, p. 131. Cf. J. André, op. cit., p. 146.

${ }_{136}$ E. SERENI, op. cit., p. 131.

${ }^{137}$ E. Sereni, op. cit., p. 131, note 318 (cetera: E. Sereni, Commentary). Cf. A.J. Carnoy, op. cit., p. 170.

${ }^{138}$ E. SERENI, op. cit., p. 131, note 318.

${ }_{139}^{139}$ J. ANDRÉ, op. cit., p. 146, note 129.

${ }^{140}$ Ibidem.

${ }^{141}$ Dominicus Bo, Auli Persii Flacci lexicon, Hildesheim 1967, s.v. tuccetum. Cf. F. CaIrns, Roman lyric. Collected papers on Catullus and Horace, Berlin-Boston 2012, p. 119.

${ }^{142}$ F. Cairns, op. cit., p. 119. Cf. Martial, Epigrammata, XII, 41.

${ }^{143}$ Cf. John of Lydia, De magistratibus populi Romani, 23, 16, [in:] IoAnnes Lydus, On powers or the magistracies of the Roman state, ed. A.C. BANDY, Philadelphia 1983.

${ }^{144}$ The aroma could have been the result of salt-curing, cf. F. Frost, op. cit., p. 245.
} 
derives from Gaul, it was spread to Italian peninsula and eastward, to the capitol of Byzantine Empire.

Having led our analysis to an end, it is time for summary. Thanks to the usage of salt as preservative, ancient Greeks and Romans learned to prepare different kinds of cured meats. The above-mentioned information indicate that ham and bacon were widely consumed in the Mediterranean area and the latter was very popular in Gaul. Cured meats were eaten raw, cooked, baked or smoked, as a main course or added to other dishes. Due to a long time of preservation, they became an important element of the diet of people who served in the army or had to travel long distances by land or sea. This kind of food was not only a significant source of protein, but, it was also valued because of its dietetic properties. Salted meat was also commonly used by ancient and Byzantine physicians in medical treatment (e.g. arthritis or parasites). Another type of nourishment was tuccetum, a meat dish, that probably came to Imperium Romanum from Gaul. According to sources it was made from pork or beef cured in greasy brine. Since it is rarely mentioned (mainly in Latin texts), we can assume that it was not so popular as ham or bacon.

\begin{abstract}
The present study discusses the role of salt-cured meat in dietetics, medicine and gastronomy demonstrated mainly in ancient and Byzantine medical (Galen, Oribasius, Aetius of Amida, Anthimus, Alexander of Tralles and Paul of Aegina) and agronomic (Cato, Varro, Columella, Palladius, Geoponica) sources written between $2^{\text {nd }}$ and $10^{\text {th }}$ century A.D. The part dealing with culinary application was also based on De re coquinaria.

The article consists of three parts. In the first one, concerning ham, there are presented places in Europe and Asia Minor, were best cured meats were produced. Next, there in an outline of different methods of salting pork, dietetic properties of this kind of food, as well as, the way of using ham in medical treatment. There are also quotations of some recipes for ham that were presented in De re coquinaria. The second, sets forth the importance of bacon in ancient and Byzantine diet and medicine, especially among inhabitants of Gaul. The authors describe also the way it was utilized in by Byzantine physicians in fighting parasites. The last part is devoted to tuccetum - a meat dish, that was only mentioned in few Latin sources and has not yet been researched in detail. Moreover there is a presentation of different ideas for translations of this Latin term given by translators, linguists and historians.
\end{abstract}

Keywords: cured meats in Antiquity and Byzantium; ham in ancient and Byzantine diet; bacon in ancient and Byzantine diet; tuccetum; meat in ancient and Byzantine medicine.

Zofia Rzeźnicka

Katedra Historii Bizancjum Wydział Filozoficzno-Historyczny Uniwersytet Łódzki ul. A. Kamińskiego 27a 90-219 Łódź, Polska zosia_pwp.historyk@wp.pl 
Maciej Kokoszko

Katedra Historii Bizancjum Wydział Filozoficzno-Historyczny Uniwersytet Łódzki ul. A. Kamińskiego 27a 90-219 Łódź, Polska mkokoszko@komandor.pl

Krzysztof Jagusiak

Katedra Historii Bizancjum Wydział Filozoficzno-Historyczny Uniwersytet Łódzki ul. A. Kamińskiego 27a 90-219 Łódź, Polska krzysztof_jagusiak@o2.pl 